\title{
The Use of Primaries by Political Parties: The Case of PASOK - A Rejoinder
}

\author{
By Gregory T. Papanikos*
}

\begin{abstract}
This note is a rejoinder to a comment made by Professor Domenico Fruncillo on my paper published in the previous issue of this journal. My aim here is to respond to his valuable comments. I have selected what I consider as the most important ones, which include the role of primary elections in promoting democracy and a specific one referring to the age effect (young versus old) in determining the result. My point of view is that primary elections should be seen as the first necessary step towards improving the democratic process; the same method can be later used to decide on issues of ideology and policies. My response to the latter important issue is as follows. The real debate in PASOK's case was not between old and young, but between those who were involved in holding government positions in the past (one prime minister and three ministers were running for PASOK's presidency), and those who did not. Of course, this is strongly correlated with age.
\end{abstract}

Keywords: primaries, elections, voting, political parties, PASOK, Greece

Professor Fruncillo's (2022) comment on my paper published in a special issue of this journal (Papanikos 2022a, 2022b) is an important contribution to the debate currently taking place in many European countries and elsewhere in the world about democracy, both by its enemies and its friends. One of the arguments in this debate is the role of political parties in a system of representative democracy, which is a second-best in organizing a contemporary politeia. The first best is a direct democracy. On the other hand, Plato's ideal system lies, for the time being, in the stratosphere of utopianism. My arguments about democracy have been presented elsewhere in Papanikos (2022c, 2022d). I am not repeating them here.

Let me start my response with a question: What is the criticism raised against the system of representative democracy? The most important criticism is the alienation of the voters from the main political decision-making processes, which allegedly take place behind closed doors. Bureaucracy and centralization are two words, which usually characterizes this system. My theoretical argument, not made in the paper, but was underlying it, was something that Professor Fruncillo so astutely pointed out, that democracy is a political system which not only is desirable, but cannot be taken for granted. It needs continuing improvements. Of course, perfectionism is something which might lead, at the end of the day, to undermining democracy itself. I have in mind Plato's ideal politeia and what happened when he had the opportunity to implement it in Syracuse- not by people's demand, but taken the permission (dictation) from a benevolent tyrant. The moral of the story is that democracy cannot be implemented from the top, but

*President, Athens Institute for Education and Research, Greece; Honorary Professor of Economics, University of Stirling, UK; and Professor, MLC Ljubljana, Slovenia. 
it requires a bottom-up approach. This is my reading of Professor Fruncillo's comment on my paper.

I think Professor Fruncillo raises an important question: Do primary elections imply more or less democracy? My answer is an unequivocal "yes". Democracy is about choices. If I am faced with an option to select a leader of my party through a process of primary elections or through a party congress, I would prefer the former because I perceive it as enhancing democracy. In relative terms, party congresses restrict democracy. Thus, being an "improvenist" and not a perfectionist (which implies the perfect or nothing else), I consider primary elections as being better than the election of the leader by a party congress. PASOK's experiences with party congresses and primary elections do not reject my hypothesis, but this requires a brand new and long paper to analyze it. I leave it for a future study.

I totally agree with Professor Fruncillo's warnings that primary elections, especially the open system of organizing them, may lead to the alienation of party members and undermine the role of political parties - at least as these parties have been developed in the post-war period. I also agree that electing a leader through primary elections may stifle any discussion and decision on ideology and policy matters.

These are important issues and I want to deal with them here. Firstly, competition between candidates for a party leadership does not necessary exclude the competition on ideas (ideology) and policies. This was definitely the case in PASOK's primary elections of 2021 and it was explicitly mentioned in my paper. The extensive publicity of the primaries gave the opportunity to less-favored candidates to express their ideology and policies and to be heard by a very wide public, political audience, which included many voters of other parties as well. This would never have been possible without the primary elections.

Secondly, I see the primary elections for electing a leader as the first necessary step towards a process of direct democracy. The fear that primary elections may split and dichotomize a political party based strictly on personal characteristics and differences was not realized in PASOK's primary elections. The debate was a very civilized one. It was considered as one of the best in the Greek political history.

The next step towards enhancing democracy is to apply the process of primary elections in selecting leaders to a process which will decide on ideological and policy matters. Then, the justified fear of Professor Fruncillo that the leader of a party becomes more independent from the party itself may be mitigated because the leader will be constrained by the decision taken by an open process of primary elections on issues this time.

Professor Fruncillo raises another important issue, which I think the abovementioned process may satisfy. He states that would be of interest to examine "... the appeal of ideology with reference to the different types of participants in the primaries." Given the analysis in my paper, it seems that voters selected a candidate whose ideology reflected the core of PASOK. This is not an accident. The new leader is a standard example of a party member who was able to be elected to party positions starting from a rank-and-file member; he was then elected to represent the party's local student union; then the youth of PASOK; thereafter he was elected Secretary General of PASOK, and finally he was elected 
a member of the European Parliament through direct elections competing with other party members as well. Now, at the age of 42 , he emerged as party leader. In that sense, his ideology is almost identical with PASOK's mainstream ideology, otherwise it would have been very difficult for him to climb all the steps of the ladder to the top.

Of course, his big challenge-responding to Professor Fruncillo's comment on what would happen now-is the next general elections scheduled for 2023. As I have argued (Papanikos 2022e) in a working paper (in Greek), if he comes second and not third (as currently is predicted by the gallops), then in the following after the next general elections, quite likely, he will be the next Prime Minister of Greece. If he fails to come second and ends up third, it is quite possible, then, that PASOK will enter into a long period of uncertainty, and the end of it might be the end of PASOK itself.

The last issue raised by Professor Fruncillo is the role of age. This was a really thorny issue, but my explanation is different from many other media commentators. I think PASOK voters (friends and members) chose a younger candidate-not the youngest though-because of his lack of experience with government responsibilities during PASOK's long periods of being the ruling party of Greece. Even though this sounds odd, it quite possibly reflects a wider electorate who believes in the ideology of center-left, but they blame all those who held government positions in the past as either betraying the ideology of the center-left in favor of a right-wing ideology and policy, or they were incompetent in implementing policies which would have reflected their ideology. Professor Fruncillo considers the argument of mobilization of friends and party members to turn out and vote for the ex-prime minister of Greece, who was the second runner-up, as unconvincing, but the numbers of the turnout and his dismal performance-far away from what expected - do not leave much room for another interpretation.

In concluding, I should mention that democracy faces two dangers. A weak one relates to populism, especially in the European countries as was recently demonstrated by Colonescu (2022) among many others, but also in Brazil and Latin America as shown by De Caria Patrício (2022) as well as in the special issue in this journal, see Maddaloni (2017) and Fruncillo (2017). This leads to the dominance of leaders; a good example is given by Buskila et al. (2022) for the case of Benjamin Netanyahu in Israel. This is not a real threat. Since antiquity, democracy cannot survive without populism and demagogues.

On the other hand, what is a real threat to democracy is the extreme radicalization of the youth, who turn into a group of organized violence and crime. If this continues, then many people would accept the solution of all kinds of dictatorships and the abolishment of democracy. A recent study which examines the youth radicalization of a European country was published by Brutovská and Béreš (2022) for Slovakia. As pointed out in Papanikos (2022d), democracy needs education, and of course eligible citizens, who are aware of the issues. The latter is not an easy objective to achieve in a democracy as is demonstrated by Al Marrar and Allevato (2022).

Overall, I really appreciate the comments made by Professor Fruncillo which I think will widen our understanding of the democratic processes in Europe. I am 
sure many more papers will be published on the issue in the future as more and more politicians reevaluate their positions towards enhancing democracy in countries where it is valued most, i.e., European democracies.

\section{References}

Al Marrar M, E Allevato (2022) Cognitive dissonance: affecting party orientation and selective recall of political information. Athens Journal of Social Sciences 9(2): 115140.

Buskila Y, Chem Levi T, Kayne A (2022) "If you rake me over the coals..." - The emotional intelligence of Benjamin Netanyahu: the Prime Minister of Israel, as perceived by Israeli citizens. Athens Journal of Social Sciences 9(2): 181-200.

Brutovská G, M Béreš (2022) How do revolting young people become radicals - The case of Slovakia. Athens Journal of Social Sciences 9(2): 161-180.

Colonescu C (2022) Measures of populism in the CHES 2017 dataset. Athens Journal of Social Sciences 9(2): 95-114.

De Caria Patrício R (2022) Brazil: country on hold, political tension running high. Athens Journal of Social Sciences 9(2): 141-160.

Fruncillo D (2017) Populism and the Italian electorate: towards a democracy without parties? Athens Journal of Social Sciences 4(3): 285-310.

Fruncillo D (2022) The use of primaries by political parties: the case of PASOK: a comment. Athens Journal of Social Sciences 9(3): 297-300.

Maddaloni D (2017) Special issue on southern European countries facing neoliberal globalization: an introduction. Athens Journal of Social Sciences 4(3): 207-210.

Papanikos GT (2022a) The use of primaries by political parties: the case of PASOK. Athens Journal of Social Sciences 9(2): 201-222.

Papanikos GT (2022b) Democracy and Politics: An Introduction to the Special Issue of the Athens Journal of Social Sciences. Athens Journal of Social Sciences 9(2): 8994.

Papanikos GT (2022c) The bright future of democracy is in education. Athens Journal of Education 9(2): 353-364.

Papanikos GT (2022d). The five ancient criteria of democracy: the apotheosis of equality. Athens Journal of Humanities \& Arts (forthcoming).

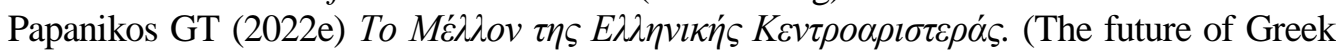
center-left). Working Paper No. 01/2022. Available at: https://bit.ly/3FUywEO. 